\title{
Apical Extrusion of Sodium Hypochlorite using Various Mechanical Activators
}

\author{
${ }^{1}$ Amulya Vangala, ${ }^{2}$ Saurabh R Doshi, ${ }^{3}$ Anisha Aparadh, ${ }^{4}$ Vivek Hegde
}

\begin{abstract}
Aim: To evaluate the volume of sodium hypochlorite extruded from the apex on using various mechanical activators.

Materials and methods: Forty extracted single-rooted mandibular premolar teeth were taken. Standardized access opening with chemicomechanical preparation till protaper $\mathrm{F} 3$ was done with $2 \mathrm{~mL}$ of $5.25 \%$ sodium hypochlorite in between instrumentation of each file. The apical patency was checked with $10 \mathrm{~K}$ file. The teeth were then divided into four groups: Group I $(n=10)$ activation was done with \#20 side-vented needle; group II $(n=10)$ activation was done with GP cones; group III $(n=10)$ activation was done with Irrisafe tips; group IV $(n=10)$ activation was done with endoactivator. As much as $10 \mathrm{~mL}$ of $5.25 \%$ sodium hypochlorite has been used with each group to activate the irrigant. The extruded sodium hypochlorite during activation with various systems was been collected in prepared apparatus. The obtained samples were analyzed for sodium ion concentration. Evaluation of the volume of sodium hypochlorite extruded from the apex was analyzed using absorption spectrometry. Then the above results were then statistically analyzed.
\end{abstract}

Results: Varying amount of apical extrusion was seen among the above study groups. Minimum amount of apical extrusion was seen with endoactivator. Maximum amount of apical extrusion was seen with needle irrigation followed by GP cones.

Keywords: Apical extrusion, Endoactivator, Gutta-percha, Irrisafe, Side-vented needle, Sodium hypochlorite.

How to cite this article: Vangala A, Doshi SR, Aparadh A, Hegde V. Apical Extrusion of Sodium Hypochlorite using Various Mechanical Activators. World J Dent 2016;7(3):146-149.

\section{Source of support: Nil}

Conflicts of interest: None

\section{INTRODUCTION}

Successful root canal treatment is based on the sound principles of debridement, disinfection, and obturation. The eradication of remnants of pulp tissue and its debris, microorganisms, and microbial toxins from the root canal is the main goal of biomechanical preparation. ${ }^{1}$

\footnotetext{
${ }^{1-3}$ Postgraduate Student, ${ }^{4}$ Professor

${ }^{1-4}$ Department of Conservative Dentistry and Endodontics, M.A. Rangoonwala College of Dental Sciences \& Research Centre Pune, Maharashtra, India

Corresponding Author: Saurabh R Doshi, Postgraduate Student, Department of Conservative Dentistry and Endodontics M.A. Rangoonwala College of Dental Sciences \& Research Centre, Pune, Maharashtra, India, Phone: +919764148400 e-mail: sdsaurabhdoshi@gmail.com
}

The organic debris (vital and necrotic pulp tissue, microorganisms) and the inorganic debris (debris deposited on the canal) are difficult to clean by instrumentation. ${ }^{2,3}$ Hence, root canal irrigation is the key in cleaning and disinfecting the areas where the instrument cannot reach. ${ }^{4}$

The most commonly advocated methods are needle irrigation and manual agitation by GP cones that are easily available. To improve the penetration and effectiveness of irrigation, other mechanical devices are used. ${ }^{5}$

Irrisafe is designed for the removal of the smear layer, dentin debris, and bacteria from the canal. Irrisafe instruments are used during passive ultrasonic irrigation (PUI) with sodium hypochlorite. It is a small, parallel-shaped, and noncutting blunt-ended tip. ${ }^{6}$

Endoactivator system comprises a cordless, contraangled, three-speed battery-operated handpiece. The tips made from medical-grade polymer are strong and appropriately flexible. It provides safe, easy, and affordable method designed to clean root canal system. ${ }^{7}$

There is no irrigant that fulfills all the ideal properties required for irrigation, such as smear layer removal, broad antimicrobial activity, less surface tension, and less cytotoxicity. Sodium hypochlorite is one of the most commonly used and widely accepted irrigants in dentistry. Despite strict control of working length during root canal preparation, extrusion of the irrigant into the periapical tissues may occur, which may result in periapical inflammation, pain, and delayed healing. ${ }^{8-11}$ Numerous clinical cases have been reported regarding complications as a result of sodium hypochlorite extrusion beyond the root canal system into the periapical tissues. ${ }^{12,13}$

Based on this literature, the purpose of this study is to evaluate the volume of sodium hypochlorite extruded apically on activation with the aforementioned techniques.

\section{MATERIALS AND METHODS}

Freshly extracted 40 single-rooted, noncarious mandibular premolar teeth were taken. Standard access opening was done for all the teeth and chemomechanical preparation was done till F3 Protaper (DENTSPLY) with 5.25\% sodium hypochlorite in between each instrument.

The apical patency of the canal was checked with 10 no. $\mathrm{K}$ file in between the instrumentation of each file. All the teeth were mounted on a test tube using a rubber base material. The teeth were divided into four study 
groups and $10 \mathrm{~mL}$ of sodium hypochlorite was used for activation. Group $1(\mathrm{n}=10)$ : (Fig. 1$)$

Final irrigant was activated with \#30 gage side-vented needle. The needle was introduced into the root canal until it bounded to the root canal, and the needle was withdrawn $1 \mathrm{~mm}$ so that it was no longer in contact with the root canal walls. Then the irrigation solution was deposited and irrigated within the root canal for 5 minutes. Group 2 ( $n=10)$ : (Fig. 2).

Final irrigant was activated with GP cones 25/06. In this group, sodium hypochlorite was introduced into the root canal and then activated using GP cones for 5 minutes in push-and-pull motion. Group $3(n=10)$ : (Fig. 3)

Final irrigant was activated with Irrisafe \#25. In this group, sodium hypochlorite was introduced into the root canal and then it was activated using Irrisafe tip for 5 minutes with the tip placed $1 \mathrm{~mm}$ short of the apex as per the manufacturer's instructions. Group $4(n=10)$ : (Fig. 4$)$

Final irrigant was activated with endoactivator 25/04. In this group, sodium hypochlorite was introduced

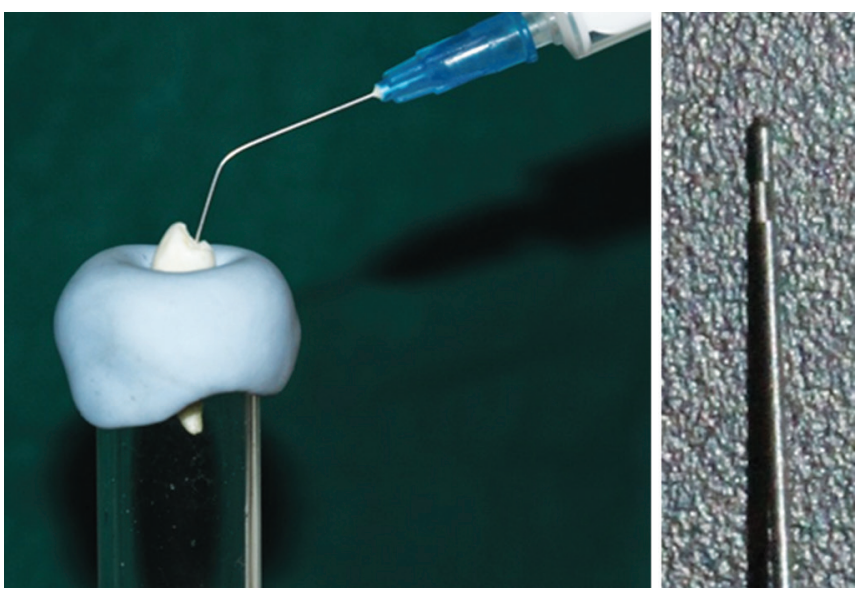

Fig. 1: Final irrigant was activated with $\# 30$ gage side-vented needle
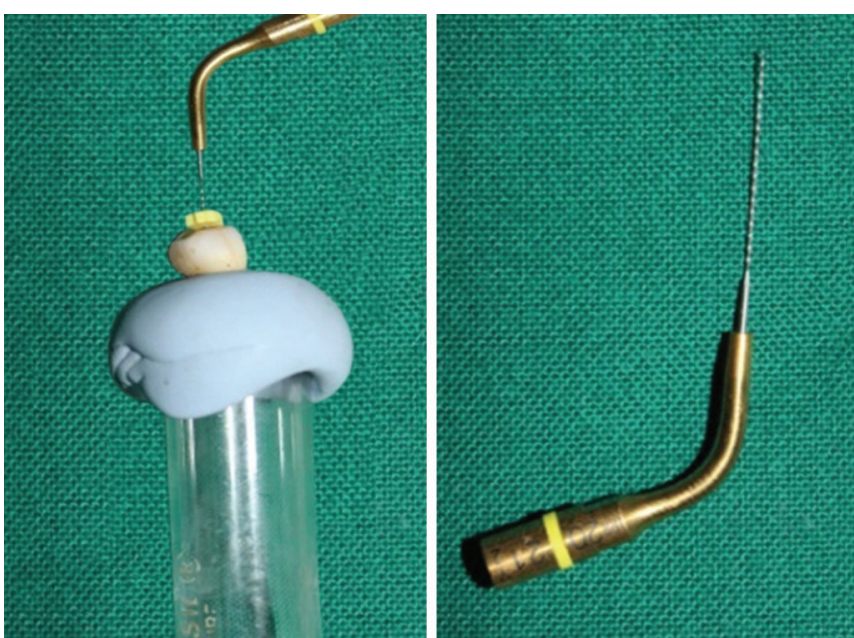

Fig. 3: Final irrigant was activated with Irrisafe \#25 into the canal and then activated with endoactivator for 5 minutes with the tip placed $1 \mathrm{~mm}$ short of the apex as per the manufacturer's instructions.

As much as $10 \mathrm{~mL}$ of $5.25 \%$ sodium hypochlorite has been used with respective group to activate the irrigation and extruded sodium hypochlorite has been collected in apparatus (Fig. 5).

Then all the samples were analyzed for sodium ion concentration in collected apparatus using absorption spectrometry (Fig. 6).

The mean concentration of sodium in $5.25 \%$ of sodium hypochlorite is $25.06 \mathrm{mg} / \mathrm{mL}$. The following method was used to calculate the volume of sodium hypochlorite extruded beyond apex of the teeth. ${ }^{14}$

$$
\begin{gathered}
Z=1 \mathrm{~mL}+X \\
Y=\frac{\text { Total sodium }}{\text { Total volume }} \\
X=\frac{Y}{25.06-Y}
\end{gathered}
$$

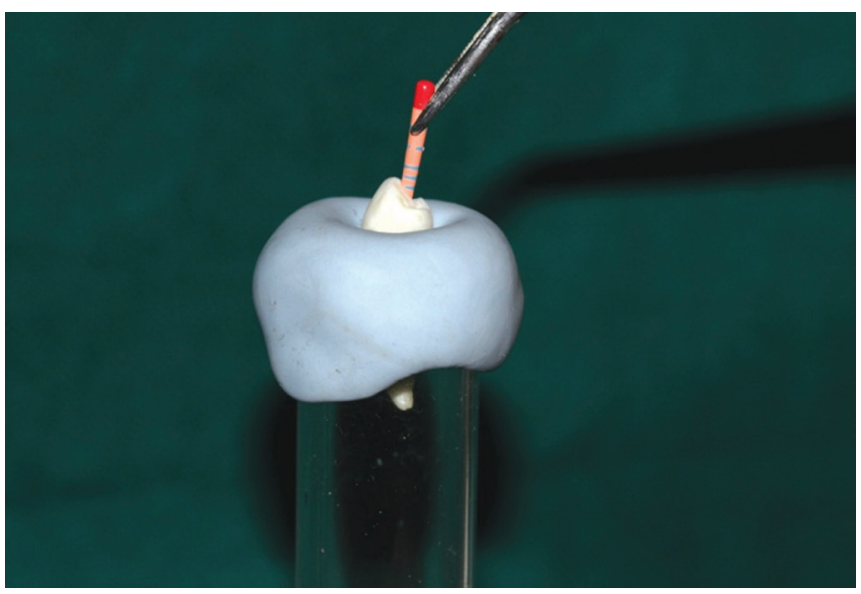

Fig. 2: Final irrigant was activated with GP cones $25 / 06$
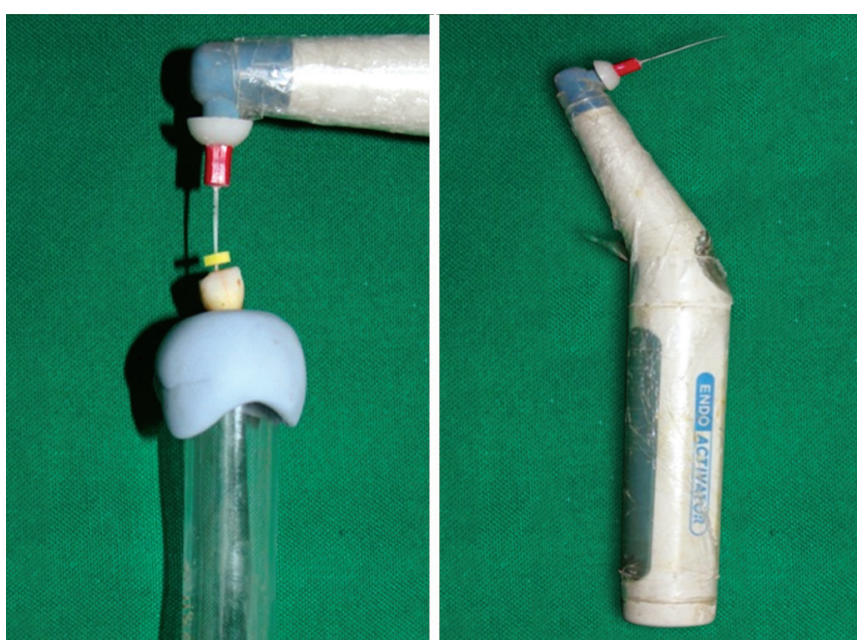

Fig. 4: Final irrigant was activated with endoactivator 25/04 

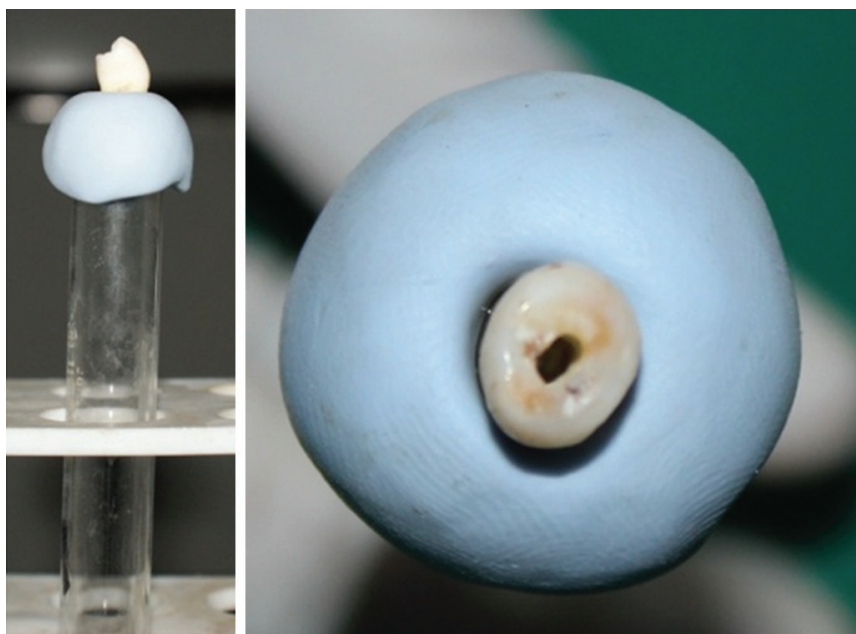

Fig. 5: Apparatus consisting of test tube, rubber base material and tooth sample

$\mathrm{Z}$ is the total volume of sodium in the apparatus; $\mathrm{Y}$ is the measured sodium concentration using sodium hypochlorite; and $\mathrm{X}$ is the volume of sodium hypochlorite extruded through the apex.

\section{RESULTS}

The result showed that the apical extrusion of sodium hypochlorite was found to be in the following order shown in the Graph 1.

$p$ values are obtained using one-way analysis of variance (ANOVA) with post hoc Tukey's correction for multiple group comparisons after confirming the underlying normality assumption.

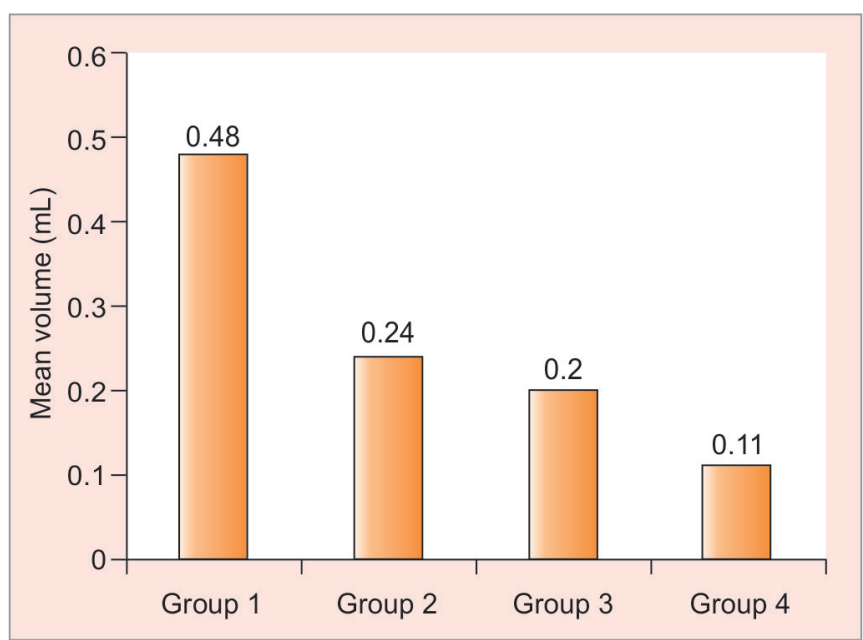

Graph 1: Apical extrusion of sodium hypohlorite

Table 1: Comparison between the groups of volume of sodium hypochlorite

\begin{tabular}{lllll}
\hline Volume $(m L)$ & $\begin{array}{l}\text { Group 1 } \\
(n=10)\end{array}$ & $\begin{array}{l}\text { Group 2 } \\
(n=10)\end{array}$ & $\begin{array}{l}\text { Group 3 } \\
(n=10)\end{array}$ & $\begin{array}{l}\text { Group 4 } \\
(n=10)\end{array}$ \\
\hline Mean \pm SD & $0.48 \pm 0.39$ & $0.24 \pm 0.14$ & $0.20 \pm 0.20$ & $0.11 \pm 0.10$ \\
Median & 0.33 & 0.16 & 0.10 & 0.075 \\
(Min-Max) & $(0.08-1.04)$ & $(0.01-0.59)$ & $(0.03-0.71)$ & $(0.01-0.32)$ \\
\hline
\end{tabular}

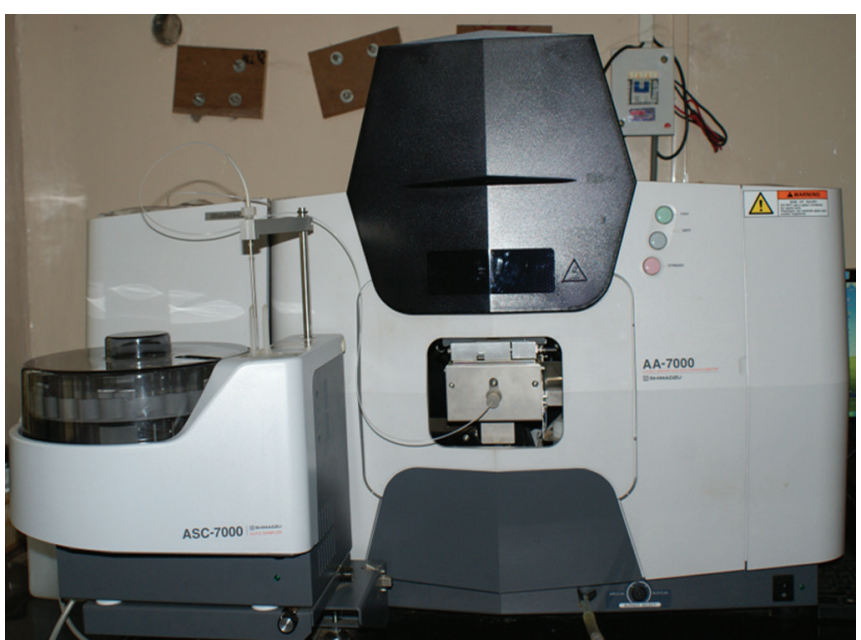

Fig. 6: Absorption spectrometry

$\mathrm{p}$-value $<0.05$ is considered to be statistically significant (Table 1).

\section{DISCUSSION}

Sodium hypochlorite is used as an irrigant as it effectively dissolves the vital and nonvital tissues, and also it is an effective antimicrobial. ${ }^{15}$

The use of ultrasonic energy with an irrigant contributed to better cleaning of the root canal system than irrigation and hand instrumentation alone. ${ }^{15}$ In this study, the activation was done with various mechanical activators, such as side-vented needle, GP cones, Irrisafe, and endoactivator to enhance the effect of the irrigant in eliminating the bacteria.

But with irrigation and the activation of the irrigant, there are more chances of the irrigant extruding apically, which may lead to patients experiencing postprocedural pain and endodontic flare-ups. ${ }^{14}$ Therefore, this study emphasizes on the amount of apical extrusion of sodium hypochlorite during its activation.

Varying amount of apical extrusion was seen among the study groups mentioned. Minimum amount of apical extrusion was seen with endoactivator. Maximum amount of apical extrusion was seen with needle irrigation, followed by that with GP cones.

The endoactivator had minimal amount of irrigant extruded from the apex while delivering the irrigant into the pulp chamber and initiating sonic energy of endoactivator. During use, the action of the vibrating tip frequently produces a "cloud" of debris that can be clinically observed in a fluid-filled pulp chamber. This hydrodynamic activation serves to improve the penetration, circulation, and flow of irrigant into the more inaccessible regions of the root canal system. ${ }^{16}$

In an ultrasonic system with Irrisafe tip, the agitation of fluid in the canal with passive activation created more 
turbulence of the fluids, resulting in effective removal of the debris from the root canal system. ${ }^{17}$

Irrisafe tip showed more fluid extrusion beyond the apex than endoactivator. This could be because PUI creates cavitation and acoustic streaming, but sonic energy produces only acoustic streaming, leading to less removal of debris from canal walls, which, in turn, causes less apical extrusion. ${ }^{18}$

Brown et $\mathrm{al}^{14}$ has concluded that the use of a reservoir of irrigation in the coronal access cavity results in significantly less apical extrusion of irrigation solution than with deep delivery.

Significantly maximum amount of extrusion was seen with needle irrigation compared to GP cones. This may be due to the different pressure being exerted apically within the canals. When hand filing is continued, it causes the hydrostatic pressure sufficiently to force the fluid beyond the apex.

The clinical significance of apical extrusion during the preparation is unknown, but the destruction of periapical tissue by sodium hypochlorite is documented. However, apical extrusion of irrigant was found to be minimal with endoactivator system.

Clinicians should consider the biocompatibility of the irrigating solution, the method of delivery of the solution, and method of instrumentation during clinical preparation to avoid undue consequences.

\section{CONCLUSION}

Within the limitations of the study, we can conclude that: There is no ideal irrigation system with virtually no apical extrusion. Although, currently, irrigation systems, such as endoactivator have a clinical advantage over other irrigation techniques of minimal apical extrusion; thus, proving that sonic activation of instruments not only removes debris but also has minimal apical extrusion of sodium hypochlorite as compared to all available irrigation systems.

\section{REFERENCES}

1. Shin SJ, Kim HK, Jung IY, Lee CY, Lee SJ, Kim E. Comparison of the cleaning efficacy of a new apical negative pressure irrigating system with conventional irrigation needles in the root canals. Oral Surg Oral Med Oral Pathol Oral Radiol Endod 2010 Mar;109(3):479-484.

2. Ribeiro EM,Silva-Sousa YT,Souza-Gabriel AE,Sousa-NetoMD, Lorencetti KT, Silva SR. Debris and smear removal in flattened root canals after use of different irrigant agitation protocols. Microsc Res Tech 2012 Jun;75(6):781-790.

3. Desai P, Himel V. Comparative safety of various intracanal irrigation systems. J Endod 2009 Apr;35(4):545-549.

4. Haapasalo M, Endal U, Zandi H, Coil JM. Eradication of endodontic infection by instrumentation and irrigation solutions. Endod Top 2005 Mar;10(1):77-102.

5. Chow TW. Mechanical effectiveness of root canal irrigation. J Endod 1983 Nov;9(11):475-479.

6. Ahmad M, Pitt Ford TJ, Crum LA. Ultrasonic debridement of root canals: acoustic streaming and its possible role. J Endod 1987 Oct;13(10):490-499.

7. Ruddle CJ. Advanced endodontics. Dentistry Today; 2009 Nov.

8. Pashley EL, Birdsong NL, Bowman K, Pashley DH. Cytotoxic effects of sodium hypochlorite on vital tissue. J Endod 1985 Dec;11(12):525-528.

9. Gernhardt CR, Eppendorf K, Kozlowski A, Brandt M. Toxicity of concentrated sodium hypochlorite used as an endodontic irrigant. Int Endod J 2004 Apr;37(4):272-280.

10. Hulsmann M, Hahn W. Complications during root canal irrigation-literature review and case reports. Int Endod J 2000 May;33(3):186-193.

11. Kleier DJ, Averbach RE, Mehdipour O. The sodium hypochlorite accident: experience of diplomates of the American Board of Endodontics. J Endod 2008 Nov;34(11):1346-1350.

12. Becker G, Cohen S, Borer R. The sequelae of accidentally injecting sodium hypochlorite beyond the root apex. Oral Surg Oral Med Oral Pathol 1974 Oct;38(4):633-638.

13. Gatot A, Arbelle J, Leiberman A, Yanai-Inbar I. Effects of sodium hypochlorite on soft tissues after its inadvertent injection beyond the root apex. J Endod 1991 Nov;17(11):573-574.

14. Brown DC, Moore BK, Brown CE Jr, Newton CW. An in vitro study of apical extrusion of sodium hypochiorite during endodontic canal preparation. J Endod 1995 Dec;21(12):587-591.

15. Cathro P. The importance of irrigation in endodontics. Endod Solutions Online 2004 Spring;10(1):1-4.

16. Ruddle CJ. Cleaning and shaping the root canal system. In Cohen S, Burns RC, editors. Pathways of the pulp. 8th ed. St. Louis (MO): Mosby; 2002. p. 231-291.

17. Townsend C, Maki J. An in vitro comparison of new irrigation and agitation techniques to ultrasonic agitation in removing bacteria from a simulated root canal. J Endod 2009 Jul;35(7):1040-1043.

18. UP Nair et al. Comparative evaluation of debris removal from root canal systems. Rev Rom Stomatol 2011 57(1):67-70. 